\title{
Evaluating the effect of injecting triamcinolone acetonide in two sessions for preventing esophageal stricture after endoscopic submucosal dissection
}

\section{(ㄷ)(1) $(-)$}

Authors

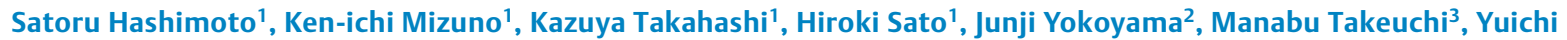
Sato ${ }^{4}$, Masaaki Kobayashi ${ }^{5}$, Shuji Terai ${ }^{1}$

Institutions

1 Niigata University Medical and Dental Hospital, Division of Gastroenterology and Hepatology, Niigata, Japan

2 Niigata University Medical and Dental Hospital, Department of Endoscopy, Niigata, Japan

3 Nagaoka Red Cross Hospital, Department of Gastroenterology, Niigata, Japan

4 Niigata Prefecture Yoshida Hospital, Department of Gastroenterology, Niigata, Japan

5 Niigata Cancer Center Hospital, Department of Gastroenterology, Niigata, Japan

submitted 23.9.2018

accepted after revision 14.3.2019

\author{
Bibliography \\ DOI https://doi.org/10.1055/a-0894-4374 | \\ Endoscopy International Open 2019; 07: E764-E770 \\ (c) Georg Thieme Verlag KG Stuttgart · New York \\ elSSN 2196-9736
}

Corresponding author

Satoru Hashimoto, Division of Gastroenterology and Hepatology, Niigata University Medical and Dental Hospital, 1-757 Asahimachi-dori, Chuo-ku, Niigata 9518510, Japan

Fax: +81-25-227-0776

hashim@med.niigata-u.ac.jp
ABSTRACT

Background and study aims Several previous reports indicate that endoscopic injection of triamcinolone acetonide (TA) after widespread endoscopic submucosal dissection (ESD) is effective for preventing esophageal stricture. We investigated the efficacy of injecting TA in two sessions for preventing stricture formation post-ESD.

Patients and methods Sixty-six consecutive patients with widespread mucosal defects that affected more than threefourths of the circumference of the esophagus were included. The study group $(n=40)$ received TA injections over two sessions: immediately after and 14 days after ESD. The control group $(n=26)$ did not receive a TA injection. This study was performed retrospectively against historical controls. The primary endpoint of this study was frequency of stricture after TA injection. The secondary endpoint was number of required endoscopic balloon dilations (EBDs) after TA injection.

Results The post-ESD stricture rate among patients who had subcircumferential mucosal defects was $45.7 \%$ in the study group (16/35 patients), which was significantly lower than the rate of $73.9 \%$ in the control group (17/23 patients; $P=0.031)$. The number of EBD procedures required was significantly lower in the study group (median 0 , range $0-7$ ) than in the control group (median 4, range $0-20 ; P<$ 0.001 ). There was no significant difference between the study and control groups among the patients who had full circumferential mucosal defects.

Conclusion This study showed that performing two sessions of TA injection is an effective and safe treatment for prevention of esophageal stricture following subcircumferential ESD.

\section{Introduction}

Endoscopic submucosal dissection (ESD) is widely accepted in Japan as a standard therapy for superficial esophageal squamous cell carcinomas without lymph node metastasis [1,2]. An advantage of this technique compared to endoscopic mucosal resection (EMR) is that it allows en bloc resection of lesions of any size, resulting in low recurrence rates and precise histopathological evaluation. However, widespread mucosal resection within the esophageal lumen may cause severe strictures [3], thus necessitating several endoscopic balloon dilation (EBD) procedures over an extended period [4]. Therefore, development of strategies to prevent esophageal strictures following ESD would be beneficial. 


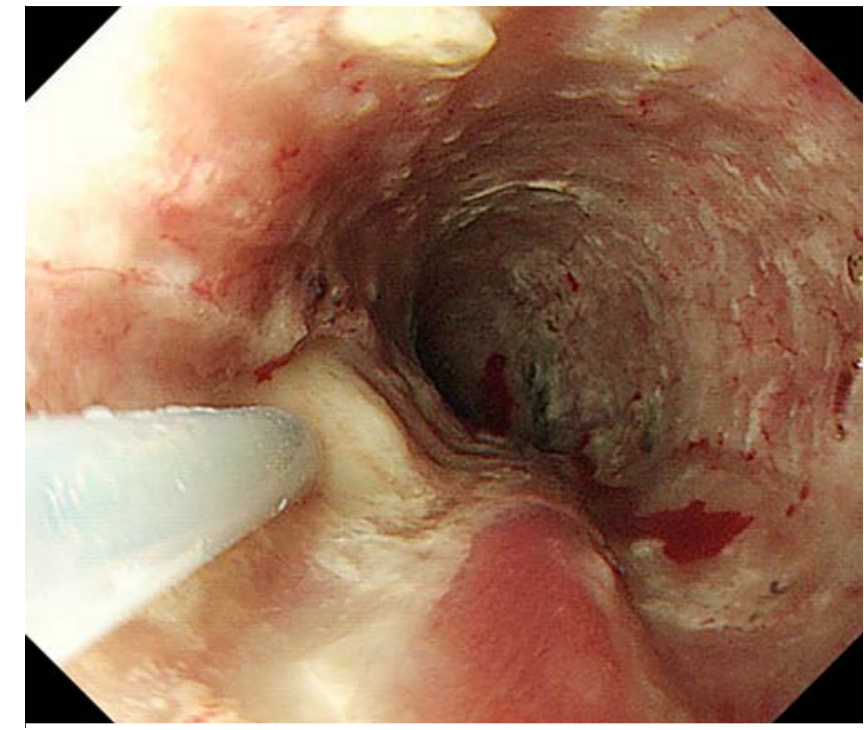

- Fig. 1 Triamcinolone acetonide was injected into the residual submucosal tissue of the cautery ulcer base after endoscopic submucosal dissection.

Several previous reports showed that endoscopic steroid injection into a cautery ulcer base after ESD is effective for prevention of esophageal stricture [5-9]. We were the first to report on the efficacy and safety of TA injection [5], and other reports have supported our finding [6-9]. However, there are differences in the method of TA injection in each report and the optimal method has not been determined. We have investigated the efficacy of injecting TA in two sessions for the prevention of stricture formation after ESD.

\section{Patients and methods}

\section{Patients}

A total of 782 patients with 939 superficial esophageal squamous cell carcinomas were treated via ESD at our hospital from February 2003 to July 2016. This study involved 66 consecutive patients with widespread mucosal defects that affected more than three-fourths of the esophageal circumference. Among these, 58 patients had subcircumferential mucosal defects that affected more than three-fourths of the esophageal circumference and eight had mucosal defects involving the entire esophageal circumference. Patients who underwent chest radiology and those who had a previous ESD scar near the lesion were excluded. The study group comprised 40 patients who received TA injection (patients treated after December 2011), and the control group comprised 26 patients who did not receive TA injection (patients treated before December 2011). The 66 patients were divided into four groups: study (n $=35)$ and control $(n=23)$ groups of patients with subcircumferential mucosal defects, and study $(n=5)$ and control $(n=3)$ groups of patients that had full circumferential mucosal defects. This retrospective study was approved by the institutional review board at Niigata University (approval number: 2017 0057).

\section{ESD procedure}

The ESD procedure was performed by five experienced endoscopists. Patients were sedated with intravenous injection of propofol or midazolam while monitoring of blood pressure, electrocardiography results, oxygen saturation, and bispectral index was performed during ESD. All ESDs were performed with an upper gastrointestinal endoscope (GIF-Q240 or GIFQ260]; Olympus Medical Systems, Tokyo, Japan) that was fitted with a transparent hood (F-020, TOP Corporation, Tokyo, Japan). Carbon dioxide insufflation was used during ESD. An electrosurgical current was applied using a standard electrosurgical generator (VIO300 D or ICC200; ERBE, Tübingen, Germany) and a Hook knife (KD-260LR, Olympus) was used as an electrosurgical knife. The tumor margin was defined using a $1.25 \%$ iodine solution and mucosal marking was performed circumferentially outside the tumor margin with the knife. Glycerol (10\% glycerin and $5 \%$ fructose) was injected into the submucosa to elevate the lesion. Bleeding vessels were coagulated using monopolar Coagrasper Hemostatic Forceps (ED-410LR, Olympus). Resected specimens were extended on boards using pins, for fixation in $10 \%$ formalin. Serial-step sections at 2 -mm intervals were made after 24 hours, stained with hematoxylin and eosin, and evaluated by pathologists. Tumor size, depth of invasion, and horizontal and vertical margin involvement were evaluated.

\section{Protocol for TA injection}

TA injection was performed using triamcinolone acetonide (Kenacort-A, $50 \mathrm{mg} / 5 \mathrm{ml}$; Bristol-Meyers Squibb, Anagni, Italy). The TA injection sessions were immediately after ESD and 14 days later (a total of 2 sessions). In the first session, TA was diluted $1: 1$ with saline to make a $5 \mathrm{mg} / \mathrm{mL}$ solution. A 25 -gauge, 1.8 $\mathrm{mm}$ needle (TOP Corporation) was used for the injections. After the needle had been inserted shallowly to avoid injuring the muscularis propria, TA was injected in aliquots of $0.5 \mathrm{~mL}$ $(2.5 \mathrm{mg})$ into the residual submucosal tissue of the cautery ulcer base. The injections were administered equally at about 10 mm intervals. - Fig. 1 shows the injection procedure. The total dose of TA in the first session ranged from 40 to $100 \mathrm{mg}$, varying with the ulcer base. In the second session, TA was administered without further dilution. A 25-gauge, 4-mm needle (TOP Corporation), which was longer than that used in the first session, was used because of the thicker submucosal layer with coagulated tissue. TA was injected in aliquots of $0.2 \mathrm{~mL}(2 \mathrm{mg})$ into the submucosal tissue of the ulcer carefully as in the first session. The total dose of TA in the second session ranged from 16 to $50 \mathrm{mg}$, varying with the ulcer base.

\section{Surveillance after ESD}

Proton pump inhibitors were administered to all patients starting from the day of ESD for prevention of gastric acid reflux. We checked for chest pain and fever, and performed chest X-ray imaging and blood examinations on the following day to determine whether complications such as delayed bleeding and perforation had occurred. Esophagoscopy was performed to assess for stenosis at 1 month, 3 months, 6 months, and 1 year after ESD. Post-ESD stricture was defined as a patient complaint of 
- Table 1 Evaluation of subcircumferential mucosal defects.

\begin{tabular}{|c|c|c|c|}
\hline & Study group ( $n=35$ ) & Control group $(n=23)$ & $P$ value \\
\hline Sex (male/female) & $31 / 4$ & $19 / 4$ & 0.7 \\
\hline Age, median (range) y & $75(56-90)$ & $68(49-90)$ & 0.066 \\
\hline Tumor location & & & 0.21 \\
\hline - Upper thoracic & 5 & 0 & \\
\hline - Middle thoracic & 18 & 13 & \\
\hline - Lower thoracic & 9 & 9 & \\
\hline - Abdominal & 3 & 1 & \\
\hline Macroscopic type & & & 0.69 \\
\hline - Elevated & 5 & 2 & \\
\hline - Flat/depressed & 30 & 21 & \\
\hline Depth of invasion & & & 0.62 \\
\hline - T1a & 29 & 19 & \\
\hline - $\mathrm{T} 1 \mathrm{~b}$ & 6 & 4 & \\
\hline Resection size, mean $\pm \mathrm{SD}, \mathrm{mm}$ & $50.3 \pm 15.4$ & $49.1 \pm 12.0$ & 0.76 \\
\hline Rate of en-bloc resection (\%) & 100 & 100 & - \\
\hline Operation time, mean $\pm S D$, min & $205.4 \pm 55.1$ & $216.8 \pm 102.8$ & 0.63 \\
\hline Time to esophageal stricture, mean \pm SD, day & $38.8 \pm 18.8$ & $21.1 \pm 11.1$ & 0.002 \\
\hline Frequency of stricture, $\mathrm{n}(\%)$ & $16(45.7)$ & $17(73.9)$ & 0.031 \\
\hline No. of required EBDs, median (range) & $0(0-7)$ & $4(0-20)$ & 0.001 \\
\hline
\end{tabular}

dysphagia to soft solids or when a standard endoscope (GIFQ240 or GIF-Q260]; Olympus) could not be passed through the ESD scar. EBD was performed with a balloon dilator (CRE Fixed Wire Balloon Dilators; Boston Scientific Japan Co., Tokyo, Japan) whenever a patient complained of dysphagia and was repeated on demand until the dysphagia resolved.

\section{Evaluation and statistical analysis}

The primary endpoint of this study was frequency of strictures after TA injection. The secondary endpoint was number of required EBDs after TA injection. All statistical analyses were performed using SPSS software, version 24 (SPSS Japan Inc, Tokyo, Japan). The independent $t$-test and the Mann-Whitney U-test were used for comparing continuous variables. The chi-square test was performed for non-continuous variables.

\section{Results}

\section{Evaluation of subcircumferential mucosal defects}

- Table 1 shows baseline data and treatment outcomes. There was no significant difference in sex, age, tumor location, macroscopic type, depth of invasion, resection size, rate of en-bloc resection, or operation time. Time to esophageal stricture in the study group $(38.8 \pm 18.8)$ was significantly longer than that in the control group $(21.1 \pm 11.1, P=0.002)$. The post-ESD stricture rate was $45.7 \%$ in the study group (16/35 patients), which was significantly lower than the $73.9 \%$ in the control group (17/23 patients; $P=0.031)$. The number of EBD procedures required was significantly lower in the study group (median 0 , range $0-7$ ) than in the control group (median 4 , range $0-20)(P<0.001)$. A representative case from the study group is shown in $\mathbf{F i g . 2}$. There were no complications or side effects, such as delayed bleeding, delayed perforation, or mediastinal abscess, associated with the injection procedure. However, perforations after EBD were recognized at 22 and 77 days after ESD in two patients in the study group and at 36 days after ESD in one patient in the control group.

\section{Evaluation of full circumferential mucosal defects}

- Table 2 shows baseline data and treatment outcomes. There was no significant difference in sex, age, tumor location, macroscopic type, depth of invasion, resection size, rate of en-bloc resection, operation time, or time to esophageal stricture. The post-ESD stricture rate was $80 \%$ in the study group (4/5 patients), which was insignificantly different compared to the $100 \%$ in the control group ( $3 / 3$ patients; $P=0.62)$. The number of required EBD procedures in the study group (median 0 , range $0-7$ ) was also insignificant compared to that in the control group (median 4 , range $0-20 ; P=0.96$ ). There were no complications or side effects associated with the injection 

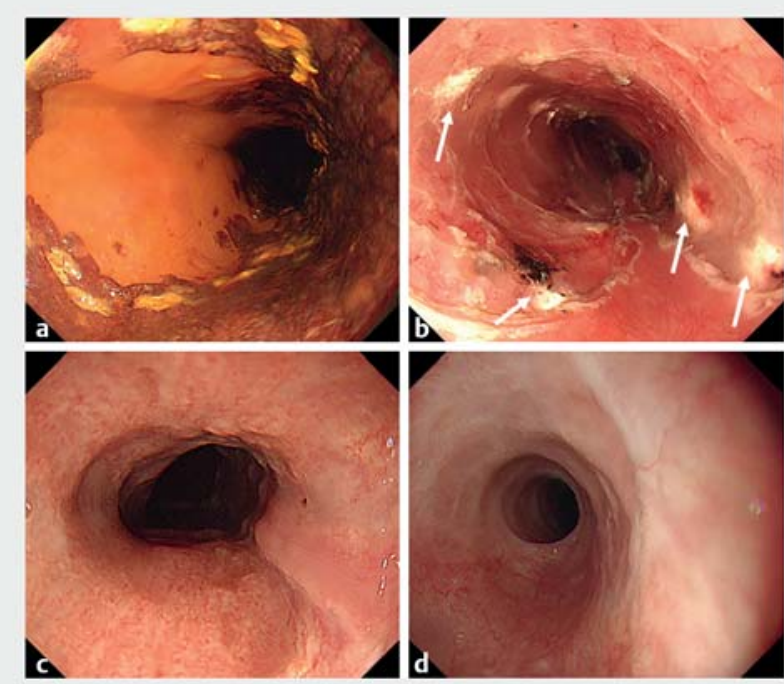

- Fig. 2 Representative endoscopic views of a patient in the study group a Chromoendoscopy with iodine staining showing a superficial esophageal carcinoma in the middle thoracic esophagus. b Subcircumferential mucosal removal was performed using endoscopic submucosal dissection (ESD). Injection of triamcinolone acetonide into the cautery ulcer base immediately after ESD (white arrow). c Endoscopic imaging on Day 14 showed no white ulcer base and no stenotic change. $\mathbf{d}$ After 3 months, complete epithelialization and no stricture were confirmed endoscopically. procedure. However, perforation after EBD was recognized at 7 days after ESD in 1 patient in the control group.

\section{Discussion}

In this study, we performed TA injections in two sessions (immediately after and 14 days after ESD) to prevent esophageal stricture after ESD. The post-ESD stricture rate and number of required EBD procedures among the patients who had subcircumferential mucosal defects were significantly lower in the study group compared to the control group. However, among patients who had full circumferential mucosal defects, there were no significant differences between the groups.

Widespread mucosal resection within the narrow esophageal lumen may result in severe strictures. Fibrosis in the submucosal layer of the esophageal wall is considered to be the cause of stricture formation. Steroids are thought to act by modulating wound healing through their anti-inflammatory effects by decreasing prolyl hydroxylase activity and by amplifying collagenase activity, thus inhibiting stricture formation [10].

Yamaguchi et al. reported that oral prednisolone is an effective treatment for preventing esophageal strictures after esophageal ESD [11]. This may be due to suppression of active inflammation and fibrosis by oral prednisolone for an extended time, such as 8 weeks. However, a case of disseminated nocar-

- Table 2 Evaluation of full circumferential mucosal defects.

\begin{tabular}{|c|c|c|c|}
\hline & Study group $(n=5)$ & Control group $(n=3)$ & $P$ value \\
\hline Sex (male/female) & $3 / 2$ & $2 / 1$ & 0.71 \\
\hline Age, median (range) y & $70(57-79)$ & $69(63-72)$ & 0.78 \\
\hline Tumor location & & & 0.12 \\
\hline - Upper thoracic & 3 & 0 & \\
\hline - Middle thoracic & 1 & 1 & \\
\hline - Lower thoracic & 1 & 1 & \\
\hline - Abdominal & 0 & 1 & \\
\hline Macroscopic type & & & 0.63 \\
\hline - Elevated & 1 & 0 & \\
\hline - Flat/depressed & 4 & 3 & \\
\hline Depth of invasion & & & 0.36 \\
\hline - T1a & 3 & 3 & \\
\hline - T1b & 2 & 0 & \\
\hline Resection size, mean $\pm \mathrm{SD}$, mm & $47.6 \pm 12.5$ & $52 \pm 7.2$ & 0.61 \\
\hline Rate of en-bloc resection (\%) & 100 & 100 & - \\
\hline Operation time, mean $\pm S D$, min & $267.5 \pm 54.4$ & $256.7 \pm 72.3$ & 0.83 \\
\hline Time to esophageal stricture, mean \pm SD, day & $34.5 \pm 8.7$ & $11.0 \pm 3.5$ & 0.057 \\
\hline Frequency of stricture, $n(\%)$ & $4(80)$ & $3(100)$ & 0.62 \\
\hline No. of required EBDs, median (range) & $7(0-11)$ & $13(6-19)$ & 0.96 \\
\hline
\end{tabular}


- Table 3 Previous studies on triamcinolone acetonide injection for prevention of esophageal stricture after endoscopic submucosal dissection.

\begin{tabular}{|c|c|c|c|c|c|c|c|}
\hline Study & Study design & $\begin{array}{l}\text { No. of } \\
\text { sub- } \\
\text { jects }\end{array}$ & $\begin{array}{l}\text { Circumference } \\
\text { of the mucosal } \\
\text { defect }\end{array}$ & $\begin{array}{l}\text { Timing } \\
\text { of TA in- } \\
\text { jection }\end{array}$ & $\begin{array}{l}\text { Total dose } \\
\text { of TA }\end{array}$ & $\begin{array}{l}\text { Definition of } \\
\text { stricture }\end{array}$ & Stricture rate \\
\hline $\begin{array}{l}\text { Hashimoto } \\
\text { S, et al. } \\
\text { (2011) [5] }\end{array}$ & Retrospective & 41 & $\begin{array}{l}\text { Subcircumfer- } \\
\text { ence }(>3 / 4)\end{array}$ & $\begin{array}{l}\text { Day } 3,7 \text {, } \\
\text { and } 10 \\
\text { (post } \\
\text { ESD) }\end{array}$ & $\begin{array}{l}18-62 \text { mg per } \\
\text { session, vary- } \\
\text { ing with ulcer } \\
\text { size }\end{array}$ & $\begin{array}{l}\text { No passage of } \\
\text { an endoscope } \\
\text { (GIF-Q240) }\end{array}$ & $19 \%$ \\
\hline $\begin{array}{l}\text { Hanaoka } \\
\text { N, et al. } \\
\text { (2012) [6] }\end{array}$ & Prospective & 59 & $\begin{array}{l}\text { Subcircumfer- } \\
\text { ence }(>3 / 4)\end{array}$ & $\begin{array}{l}\text { Day } 0 \\
\text { (post } \\
\text { ESD) }\end{array}$ & $\begin{array}{l}100 \mathrm{mg} \text { per } \\
\text { session }\end{array}$ & $\begin{array}{l}\text { Dysphagia to } \\
\text { some solids or } \\
\text { no passage of a } \\
\leq 9.2 \mathrm{~mm} \text { diame- } \\
\text { ter endoscope }\end{array}$ & $10 \%$ \\
\hline $\begin{array}{l}\text { Takahashi } \\
\text { H, et al. } \\
\text { (2015) [7] }\end{array}$ & $\begin{array}{l}\text { Prospective } \\
\text { randomized } \\
\text { controlled }\end{array}$ & 16 & $\begin{array}{l}\text { Subcircumfer- } \\
\text { ence }(>2 / 3) \text { and } \\
\text { full circumfer- } \\
\text { ence }\end{array}$ & $\begin{array}{l}\text { Day } 0 \\
\text { (post } \\
\text { ESD) }\end{array}$ & Not described & $\begin{array}{l}\text { Esophageal di- } \\
\text { ameter }<11 \mathrm{~mm} \\
\text { or inability to } \\
\text { achieve or main- } \\
\text { tain a diameter } \\
\text { of } 14 \mathrm{~mm} \text { despite } \\
\text { dilation every } \\
2-4 \text { weeks }\end{array}$ & $62.5 \%$ \\
\hline $\begin{array}{l}\text { Nagami Y, } \\
\text { et al. } \\
\text { (2017) [9] }\end{array}$ & Retrospective & 101 & $\begin{array}{l}\text { Subcircumfer- } \\
\text { ence }(>2 / 3)\end{array}$ & $\begin{array}{l}\text { Day } 0 \\
\text { (post } \\
\text { ESD) }\end{array}$ & $\begin{array}{l}80 \mathrm{mg} \text { per } \\
\text { session }\end{array}$ & $\begin{array}{l}\text { Dysphagia asso- } \\
\text { ciated with semi- } \\
\text { solid foods or no } \\
\text { passage of an } \\
\text { endoscope (GIF- } \\
\text { Q260) }\end{array}$ & $16.8 \%$ \\
\hline $\begin{array}{l}\text { This study } \\
\text { (2018) }\end{array}$ & Retrospective & 66 & $\begin{array}{l}\text { Subcircumfer- } \\
\text { ence }(>3 / 4) \text { and } \\
\text { full circumfer- } \\
\text { ence }\end{array}$ & $\begin{array}{l}\text { Day } 0 \text { and } \\
14 \text { (post } \\
\text { ESD) }\end{array}$ & $\begin{array}{l}40-100 \mathrm{mg} \\
\text { per first } \\
\text { session and } \\
16-50 \mathrm{mg} \text { per } \\
\text { second ses- } \\
\text { sion, varying } \\
\text { with ulcer size }\end{array}$ & $\begin{array}{l}\text { Dysphagia to } \\
\text { some solids or } \\
\text { no passage of } \\
\text { an endoscope } \\
\text { (GIF-Q240 or } \\
\text { GIF-Q260J) }\end{array}$ & $\begin{array}{l}\text { Subcircumfer- } \\
\text { ence; } 45.7 \% \text {, full } \\
\text { circumference; } \\
80 \%\end{array}$ \\
\hline
\end{tabular}

diosis during the course of systemic steroid therapy after ESD was reported previously [12]. It is important to be careful of severe complications such as infections, diabetes mellitus, and osteoporosis during systemic steroid treatment for prevention of esophageal stricture, especially in elderly patients with critical comorbidities.

Some previous reports suggest that TA injection is effective in preventing esophageal stricture after widespread ESD. The advantages of TA injection are its easy endoscopic procedure and lower risk of systemic complications, compared to oral steroid administration. Therefore, local injection of TA is ideal for limited esophageal mucosal defects. However, there are no standard guidelines to prevent strictures, and there are differences in the method of TA injection in each report.

- Table 3 shows results of previous studies on TA injection for prevention of esophageal stricture after ESD. We published the first report on the efficacy of TA injection [5]. Incidence of strictures was significantly lower in the TA injection group $(19.0 \%)$ than in the historical control group $(75.0 \%)$. However, as the total number of TA injections was three, it might have led to a risk of delayed perforation. Some reports exist regarding delayed perforation after TA injection $[13,14]$.

Hanaoka et al. reported in a prospective study that a single session of TA injection immediately after ESD reduced the esophageal stricture rate after ESD to $10 \%$ [6]. Nagami et al. also reported that a single session of TA injection immediately after ESD reduced the stricture rate to $16.8 \%$ [9]. In Takahashi's report, the stricture rate of $62.5 \%$ after a single session of TA injection was higher than that in the other reports; however, it included cases of full circumferential mucosal defects [7]. Because the inflammatory process starts immediately after ESD, it is ideal and important that TA injection is performed immediately after ESD. However, this results in esophageal strictures in some patients.

A previous report indicated that injected TA remains locally active for 3 to 4 weeks [15]. We planned TA injection in two sessions to maintain the effect of TA for more than a month, along with oral administration of prednisolone. Injections were performed immediately after ESD and 14 days later. The condition of the cautery ulcer due to ESD changes during this period. Soon after ESD, the cautery ulcer has little active inflammation 
and fibrosis, but 14 days later, white moss arises from the active inflammation and severe fibrosis in the submucosa, leaving little space for injection. This makes it extremely challenging to administer high volumes of TA at 14 days after ESD. Therefore, we thought that higher concentrations and lower volumes of TA were necessary for submucosal injection.

Although the stricture rate in the study group (45.7\%) was significantly lower than that in the control group (73.9\%), it was higher than in previous reports in which only one session of TA injection was performed. There may be several reasons for this. First, the inherent limitations of retrospective studies and the possibility of selection bias should be considered. A randomized, controlled study comparing single-session and two-session TA injection would have been desirable. However, there are few patients with widespread esophageal cancer that affects more than three-fourths of the esophageal circumference. Therefore, it was difficult to conduct such a study at a single center. Second, the total dose of TA in our study was smaller than that in Hanaoka's study. Their total dose of TA was 100 $\mathrm{mg}$, regardless of the size of mucosal defects due to ESD. In contrast, we set a maximum dose of $100 \mathrm{mg}$ and decreased it according to the size of the mucosal defect. An insufficient dose of TA may be the underlying reason for the higher stricture rate. Third, although the operators were five experienced endoscopists, subtle differences in their technique cannot be definitively excluded. Furthermore, we speculate that a large amount of the TA injection leaked out from the residual submucosa, especially in the second session because of submucosa hardening due to fibrosis. We considered that it was important to inject TA immediately after ESD, accurately and sufficiently as the first session.

Temporary placement of a self-expandable metallic stent is being increasingly used to prevent stricture formation after ESD. Ye et al. have reported the efficacy of fully-covered stent placement after widespread esophageal ESD [16]. They observed that the rate of stricture formation was $17.3 \%$. However, stenting carries disadvantages of migration, stent-induced stricture due to granulation tissue, and high cost.

TA injection was effective in prevention of esophageal stricture for subcircumferential ESD, but not for full circumferential ESD. We considered that treatment using TA injection alone had limited effectiveness for full circumferential ESD, as reported by Hanaoka et al. [17]. Prolonged concomitant treatment with oral prednisolone may be effective, but there is a concern about the side effects, as discussed above. New methods to prevent esophageal stenosis have been developed in recent years. Honda et al. reported that injection therapy with autologous adipose tissue-derived stromal cells (ADSCs) suppressed esophageal mucosal constriction after circumferential EMR in a canine model [18]. Perrod et al. have developed transplantation of allogenic ADSCs organized in double-cell sheets after extensive ESD in animal models [19]. ADSCs, which inhibit severe fibrosis after ESD, are expected to be applied clinically. Ohki et al. reported efficacy of endoscopic transplantation of autologous oral mucosal sheets to prevent esophageal stenosis after ESD for superficial esophageal cancer [20]. In addition, new devices to transplant cell sheets endoscopically have been developed, such as use of three-dimensional printers in a porcine model [21]. Further investigation is required to increase their efficacy for clinical application, especially for full circumferential ESD.

\section{Conclusion}

In conclusion, this study showed that TA injection in two sessions is effective and safe for prevention of esophageal stricture following subcircumferential ESD. However, given previous reports on the efficacy of single injections of TA, we consider that it is important to inject TA immediately after ESD, accurately and sufficiently as the first session. Development of a new therapy for full circumferential ESD is required.

\section{Competing interests}

None

\section{References}

[1] Fujishiro M, Yahagi N, Kakushima N et al. Endoscopic submucosal dissection of esophageal squamous cell neoplasms. Clin Gastroenterol Hepatol 2006; 4: 688-694

[2] Oyama T, Tomori A, Hotta K et al. Endoscopic submucosal dissection of early esophageal cancer. Clin Gastroenterol Hepatol 2005; 3: S6770

[3] Ono S, Fujishiro M, Niimi K et al. Predictors of postoperative stricture after esophageal endoscopic submucosal dissection for superficial squamous cell neoplasms. Endoscopy 2009; 41: 661-665

[4] Katada C, Muto M, Manabe T et al. Esophageal stenosis after endoscopic mucosal resection of superficial esophageal lesions. Gastrointest Endosc 2003; 57: 165 - 169

[5] Hashimoto S, Kobayashi M, Takeuchi M et al. The efficacy of endoscopic triamcinolone injection for the prevention of esophageal stricture after endoscopic submucosal dissection. Gastrointest Endosc 2011; 74: 1389-1393

[6] Hanaoka N, Ishihara R, Takeuchi Y et al. Intralesional steroid injection to prevent stricture after endoscopic submucosal dissection for esophageal cancer: a controlled prospective study. Endoscopy 2012; 44: $1007-1011$

[7] Takahashi H, Arimura Y, Okahara S et al. A randomized controlled trial of endoscopic steroid injection for prophylaxis of esophageal stenoses after extensive endoscopic submucosal dissection. BMC Gastroenterol 2015; 15: 1

[8] Wakahara C, Morita Y, Tanaka S et al. Optimization of steroid injection intervals for prevention of stricture after esophageal endoscopic submucosal dissection: A randomized controlled trial. Acta Gastroenterol Belg 2016; 79: 315-320

[9] Nagami Y, Ominami M, Shiba M et al. Prediction of esophageal stricture in patients given locoregional triamcinolone injections immediately after endoscopic submucosal dissection. Dig Endosc 2017: doi:10.1111/den.12946

[10] Carrico TJ, Mehrhof AI Jr, Cohen IK. Biology of wound healing. Surg Clin North Am 1984; 64: 721 - 733

[11] Yamaguchi N, Isomoto H, Nakayama T et al. Usefulness of oral prednisolone in the treatment of esophageal stricture after endoscopic submucosal dissection for superficial esophageal squamous cell carcinoma. Gastrointest Endosc 2011; 73: 1115-1121 
[12] Ishida T, Morita Y, Hoshi N et al. Disseminated nocardiosis during systemic steroid therapy for the prevention of esophageal stricture after endoscopic submucosal dissection. Dig Endosc 2015; 27: 388 391

[13] Yamashina T, Uedo N, Fujii M et al. Delayed perforation after intralesional triamcinolone injection for esophageal stricture following endoscopic submucosal dissection. Endoscopy 2013; 45: (Suppl. 02): E92

[14] Matsuda Y, Kataoka N, Yamaguchi T et al. Delayed esophageal perforation occurring with endoscopic submucosal dissection: A report of two cases. World J Gastrointest Surg 2015; 7: 123-127

[15] Roques C, Teot L. The use of corticosteroids to treat keloids: a review. Int J Low Extrem Wounds 2008; 7: 137-145

[16] Ye LP, Zheng HH, Mao XL et al. Complete circular endoscopic resection using submucosal tunnel technique combined with esophageal stent placement for circumferential superficial esophageal lesions. Surg Endosc 2016; 30: 1078 - 1085
[17] Hanaoka N, Ishihara R, Uedo N et al. Refractory strictures despite steroid injection after esophageal endoscopic resection. Endosc Int Open 2016; 4: E354-E359

[18] Honda M, Hori Y, Nakada A et al. Use of adipose tissue-derived stromal cells for prevention of esophageal stricture after circumferential EMR in a canine model. Gastrointest Endosc 2011; 73: 777-784

[19] Perrod G, Rahmi G, Pidial L et al. Cell sheet transplantation for esophageal stricture prevention after endoscopic submucosal dissection in a porcine model. PLoS One 2016; 11: e0148249

[20] Ohki T, Yamato M, Ota M et al. Prevention of esophageal stricture after endoscopic submucosal dissection using tissue-engineered cell sheets. Gastroenterology 2012; 143: 582 - 588.e2

[21] Maeda M, Kanai N, Kobayashi S et al. Endoscopic cell sheet transplantation device developed by using a 3-dimensional printer and its feasibility evaluation in a porcine model. Gastrointest Endosc 2015; 82: $147-152$ 